\title{
DNA repair genes polymorphisms and genetic susceptibility to Philadelphia-negative myeloproliferative neoplasms in a Portuguese population: The role of base excision repair genes polymorphisms
}

\author{
ANA P. AZEVEDO ${ }^{1,2}$, SUSANA N. SILVA ${ }^{1}$, JOÃO P. DE LIMA ${ }^{1}$, ALICE REICHERT ${ }^{3}$, \\ FERNANDO LIMA ${ }^{3}$, ESMERALDINA JÚNIOR ${ }^{2}$ and JOSÉ RUEFF ${ }^{1}$
}

\begin{abstract}
${ }^{1}$ Centre for Toxicogenomics and Human Health (ToxOmics), Genetics, Oncology and Human Toxicology, NOVA Medical School, Faculty of Medical Sciences, NOVA University of Lisbon, 1169-056 Lisbon; Departments of ${ }^{2}$ Clinical Pathology and ${ }^{3}$ Clinical Haematology, Hospital of São Francisco Xavier, West Lisbon Hospital Centre, 1449-005 Lisbon, Portugal
\end{abstract}

Received September 27, 2016; Accepted January 26, 2017

DOI: $10.3892 / \mathrm{ol} .2017 .6065$

\begin{abstract}
The role of base excision repair (BER) genes in Philadelphia-negative (PN)-myeloproliferative neoplasms (MPNs) susceptibility was evaluated by genotyping eight polymorphisms [apurinic/apyrimidinic endodeoxyribonuclease 1, mutY DNA glycosylase, earlier mutY homolog (E. coli) (MUTYH), 8-oxoguanine DNA glycosylase 1, poly (ADP-ribose) polymerase (PARP) 1, PARP4 and X-ray repair cross-complementing 1 (XRCC1)] in a case-control study involving 133 Caucasian Portuguese patients. The results did not reveal a correlation between individual BER polymorphisms and PN-MPNs when considered as a whole. However, stratification for essential thrombocythaemia revealed i) borderline effect/tendency to increased risk when carrying at least one variant allele for XRCC1_399 single-nucleotide polymorphism (SNP); ii) decreased risk for Janus kinase 2-positive patients carrying at least one variant allele for XRCC1_399 SNP; and iii) decreased risk in females carrying at least one variant allele for MUTYH SNP. Combination of alleles demonstrated an increased risk to PN-MPNs for one specific haplogroup. These findings may provide evidence for gene variants in susceptibility to MPNs. Indeed, common variants in DNA repair genes may hamper the capacity to repair DNA, thus increasing cancer susceptibility.
\end{abstract}

Correspondence to: Professor Susana N. Silva, Centre for Toxicogenomics and Human Health (ToxOmics), Genetics, Oncology and Human Toxicology, NOVA Medical School, Faculty of Medical Sciences, NOVA University of Lisbon, Campo dos Mártires da Pátria 130, 1169-056 Lisbon, Portugal

E-mail: snsilva@nms.unl.pt; jose.rueff@nms.unl.pt

Key words: Philadelphia-negative myeloproliferative neoplasms, genetic susceptibility, base excision repair genes polymorphisms, DNA repair

\section{Introduction}

Among myeloproliferative neoplasms (MPNs), and besides chronic myelogenous leukemia, the World Health Organization (WHO) classification includes Philadelphia-negative (PN)-MPNs, namely, polycythaemia vera $(\mathrm{PV})$, essential thrombocythaemia (ET) and primary myelofibrosis (PMF) $(1,2)$.

Major genetic insights into the pathogenesis of PN-MPNs include the identification of somatic point gain-of-function mutations in the Janus kinase 2 (JAK2) gene (V617F mutation in exon 14 first in 2005, then in exon 12) (3-7) and the myeloproliferative leukemia virus oncogene (most frequently W515), in addition to recently identified calreticulin mutations (8-11), with implications in the understanding of these diseases, their diagnosis and management. The corresponding frequencies of these mutations are $\sim 95,0$ and $0 \%$ in PV; 60, 3 and 20\% in ET; and 60, 7 and 25\% in PMF, respectively $(12,13)$.

Those mutations, however, could not fully explain the phenotypic heterogeneity of PN-MPNs. Furthermore, genetic defects still await identification in $\sim 40 \%$ of ET and PMF cases (12-14). Single-nucleotide polymorphisms (SNPs) at various loci and additional somatic genetic effects may be important for PN-MPNs phenotype definition and for prognosis evaluation, although less specific than known variations (12-16). Not all mutations involved in cancer initiation may lead to cancer. This can occur due to different variants within the same gene or between variants in different genes. The latter must be considered, as the number of passenger mutations in a tumour may modulate the effect of driver mutations, thus acting as putative modifier genes (17). Additionally, epimutations that can silence tumour-suppressor genes must be taken into account (17), which highlights the concept that, probably more important than the genes, are their levels of expression.

MPNs have high morbidity with thrombohaemorrhagic complications and risk of progression to acute myeloid 
leukemia (AML), in occasions preceded by a phase of myelofibrosis or myelodysplastic syndromes (MDS) (18). Life expectancy in patients with PV or ET is reduced compared with that in the general population $(19,20)$. The 'true' rate of transformation is not accurate due to selection bias in clinical trials and underreporting in population-based studies (21). The occurrence of leukemia in ET and PV is associated with a bad prognosis, and has been reported to occur in $5-10 \%$ of patients 10 years following the initial diagnosis $(1,22)$. It is well known that high doses of alkylating agents and combined cytoreductive treatments undoubtedly increase the risk of malignant transformation (23). However, there is also an intrinsic propensity in MPNs to progress to AML/MDS, in an extent that is not fully known $(23,24)$. It cannot be ruled out that mutational burden, polymorphic variants of several genes, ambient/dietary exposure and immune system characteristics could be predisposing factors to susceptibility to these disorders $(14,25-28)$.

DNA damage to haematopoietic precursor cells would appear to be essential for the development of leukaemia, notwithstanding DNA repair systems act to repair the DNA damage, thus maintaining genetic integrity $(29,30)$.

Several polymorphisms in DNA repair genes have been identified that may affect protein function and thus DNA damage repair, leading to susceptibility to malignancy, in spite of their low genetic penetrance $(25,29-32)$. Previous reports have identified base excision repair (BER) genes polymorphisms associated with breast and thyroid cancer risk (33-35) among other malignancies, and a nucleotide excision repair gene polymorphism displayed strong association with leukaemic transformation and development of non-myeloid malignancies in patients with ET and PV (24).

The BER pathway typically repairs a small region (1-13 nucleotides) around the damaged base, involving apurinic/apyrimidinic endodeoxyribonuclease 1 (APEX1), 8-oxoguanine DNA glycosylase 1 (OGG1), poly (ADP-ribose) polymerase (PARP) 1 or X-ray repair cross-complementing 1 (XRCC1) (36).

Several SNPs in genes of the BER pathway [APEX1, mutY DNA glycosylase, earlier mutY homolog (E. coli) (MUTYH), OGG1, PARP1, PARP4 and XRCC1] have been identified and studied for their association with the risk of leukaemia and disease outcome $(25,30,37)$.

A wider characterization of molecular genetic features in PN-MPNs may contribute to a better understanding of the pathogenesis of these diseases and provide new specific diagnostic, prognostic and therapeutic tools (14).

Since data on the role of BER gene variants in PN-MPNs are absent in the literature, the present study describes a hospital-based, case-control study in a Caucasian Portuguese population in order to help assessing a possible role of BER genes on the individual susceptibility to PN-MPNs.

\section{Materials and methods}

Study subjects. The present case-control study involved 133 Caucasian Portuguese PN-MPNs patients (80 with ET, 39 with PV and 14 with PMF) in addition to 281 age- and gender-matched controls selected within the Portuguese population, who were recruited between January 2009 and July 2016, followed and treated at the Departments of Clinical Haematology and Clinical Pathology, Hospital of São Francisco Xavier, West Lisbon Hospital Centre (Lisbon, Portugal), a public general hospital that provides healthcare to the western population of Lisbon. Diagnosis criteria for all patients were those updated by the WHO (38). For all cases, at least two control individuals $(n=281)$ without neoplastic pathology, and matched for age ( \pm 2 years), gender and ethnicity were recruited, who had no personal or family history of PN-MPNs, no previous or current malignant disease and no history of blood transfusions. All patients and controls in the study were Portuguese, with Portuguese ascendants. For each patient and control, information was recorded concerning demographic characteristics, family history of cancer, lifestyle habits (e.g. tobacco smoking and alcohol consumption) and exposure to ionizing radiation. Concerning tobacco smoking habits, former smokers were considered as non-smokers if they had stopped smoking either 2 years prior to PN-MPN diagnosis in the case of patients or 2 years prior to the inclusion date in the study in the case of controls. The recorded information was coded to assure anonymity of the participants, and written informed consent was obtained from all those involved, prior to blood withdrawal, in agreement with the Declaration of Helsinki. The present study was also conducted with approval by the institutional ethics' boards of the involved institutions (NOVA Medical School and Hospital de São Francisco Xavier, Centro Hospitalar de Lisboa Ocidental). General characteristics for PN-MPNs patients and control populations are summarized in Tables I and II.

DNA extraction. DNA was obtained from cells of peripheral blood samples through a commercially available kit (QIAamp ${ }^{\circledR}$ DNA Mini kit; Qiagen GmbH, Hilden, Germany) according to the manufacturer's protocol. All DNA samples collected were stored at $-20^{\circ} \mathrm{C}$ until analysis.

SNP selection. The appropriate SNPs analyzed in the present study were selected concerning their relevance in the DNA repair pathway $(33,34)$. All SNPs had a minor allele frequency of $>0.1$ in Caucasian populations (Table III).

Genotyping. The polymorphisms rs1130409 (APEX1), rs3219489 (MUTYH), rs1052133 (OGG1),rs1136410 (PARPl), rs13428 and rs1050112 (PARP4), and rs1799782 and rs25487 $(X R C C 1)$ were genotyped using real-time PCR reaction in a 7300 Real-Time PCR system (Applied Biosystems; Thermo Fisher Scientific, Inc., Waltham, MA, USA) with TaqMan ${ }^{\circledR}$ SNP Genotyping Assays (Thermo Fisher Scientific, Inc.), according to the manufacturer's protocol and to previous reports from our group and using primers from the Taqman kit (33,39-42), with a minor modification where the final volume of the reaction was adjusted to $10 \mu \mathrm{l}$. RT-PCR genotype determinations were conducted in $20 \%$ of samples in independent experiments (60 randomly selected individuals for the control group and 30 for the case group), and all the inconclusive samples were reanalyzed. Table III summarizes the information on the SNP genotyping assay.

$J A K 2$ V617F mutational status was determined using RT-PCR in a 7300 Real-Time PCR system with TaqMan ${ }^{\circledR}$ 
Table I. General characteristics of the Philadelphia-negative myeloproliferative neoplasm cases ( $\mathrm{n}=133)$ and control population $(\mathrm{n}=281)$.

\begin{tabular}{|c|c|c|c|}
\hline Characteristics & Cases, n $(\%)$ & Controls, n (\%) & P-value \\
\hline Gender & & & 0.780 \\
\hline Male & $61(45.9)$ & $133(47.3)$ & \\
\hline Female & $72(54.1)$ & $148(52.7)$ & \\
\hline Age, years ${ }^{a, b}$ & & & 0.622 \\
\hline $30-49$ & $16(12.0)$ & $43(15.3)$ & \\
\hline $50-69$ & $50(37.6)$ & $107(38.1)$ & \\
\hline$\geq 70$ & $67(50.4)$ & $131(46.6)$ & \\
\hline Tobacco smoking habits & & & 0.633 \\
\hline Never & $104(78.2)$ & $213(76.1)$ & \\
\hline Current & $29(21.8)$ & $67(23.9)$ & \\
\hline Alcohol consumption habits & & & $<0.0001$ \\
\hline Never & $103(77.4)$ & $191(68.2)$ & \\
\hline Social & $20(15.0)$ & $25(8.9)$ & \\
\hline Regular & $10(7.5)$ & $64(22.9)$ & \\
\hline JAK2 V617F mutation & & & 0.020 \\
\hline Yes & $99(75.0)$ & & \\
\hline ET & $58(73.4)$ & & \\
\hline PV & $34(87.2)$ & & \\
\hline PMF & $7(50.0)$ & & \\
\hline No & $33(25.0)$ & & \\
\hline
\end{tabular}

${ }^{\mathrm{a}} \mathrm{Age}$ at diagnosis for cases. ${ }^{\mathrm{b}} \mathrm{Age}$ of control population at the time of diagnosis for the matched case. ${ }^{\mathrm{c}} \mathrm{P}$-value determined by $\chi^{2}$ test. ET, essential thrombocythaemia; PV, polycythaemia vera; PMF, primary myelofibrosis.

Table II. Gender distribution for the Philadelphia-negative myeloproliferative neoplasm cases $(n=133)$.

\begin{tabular}{lcrr}
\hline Diagnosis & Patients, $\mathrm{n}$ & Male, $\mathrm{n}(\%)$ & Female, $\mathrm{n}(\%)$ \\
\hline ET & 80 & $32(40.0)$ & $48(60.0)$ \\
PV & 39 & $20(51.3)$ & $19(48.7)$ \\
PMF & 14 & $9(64.3)$ & $5(35.7)$ \\
\hline
\end{tabular}

ET, essential thrombocythaemia; PV, polycythaemia vera; PMF, primary myelofibrosis.

SNP Genotyping Assays according to the manufacturer's protocol.

Statistical analysis. The analysis of Hardy-Weinberg frequencies for all alleles in the enrolled populations was carried out using exact probability tests available in SNPstat website software (http://bioinfo.iconcologia.net/SNPstats) (43). Differences in genotype frequency, tobacco smoking/alcohol consumption status, age class and gender distributions between PN-MPNs cancer patients and controls were evaluated by the $\chi^{2}$ test. The crude and adjusted odds ratios (ORs) corresponding to $95 \%$ confidence intervals (CIs) were calculated by unconditional multiple logistic regression and statistical analysis performed with SPSS version 22.0 (IBM SPSS, Armonk, NY, USA). The adjusted OR was determined correcting the results for gender, age at diagnosis, and tobacco smoking and alcohol consumption habits.

Since the present study is not a conclusive final study, but an exploratory one, on the role of BER polymorphisms in PN-MPNs, and the data obtained should be considered as proof of concept on that possible role, the Bonferroni adjustment was deemed as not necessary, as it is too conservative.

\section{Results}

Characterization of populations. The present study included 133 PN-MPNs patients and 281 age- and gender-matched controls. According to the diagnosis criteria, the patients' distribution was as follows: 80 patients $(60.2 \%)$ with ET, 39 (29.3\%) with PV and 14 (10.5\%) with PMF (Table II). The baseline characteristics (gender, age, alcohol consumption and tobacco smoking habits) of the case and control populations are listed in Tables I and II.

The case group included $72(54.1 \%)$ females and 61 $(45.9 \%)$ males, with an overall mean age of 68 years, in agreement with the gender distribution usually observed in this type of pathology $(1,44)$. No significant differences were observed between the control and patient groups concerning age distribution or tobacco smoking habits (Table I). However, 
Table III. Selected single-nucleotide polymorphisms and detailed information on the corresponding base and amino acid exchanges as well as MAF.

\begin{tabular}{lccc}
\hline Gene & Codon & $\begin{array}{c}\text { Exchange, base } \\
\text { (amino acid) }\end{array}$ & MAF $(\%)^{\mathrm{a}}$ \\
\hline APEX1 & 148 & $\mathrm{~T} \rightarrow \mathrm{G}($ Asp/Glu) & 44.0 \\
MUTYH & 335 & $\mathrm{G} \rightarrow \mathrm{C}(\mathrm{Gln} / \mathrm{His})$ & 31.9 \\
OGG1 & 326 & $\mathrm{C} \rightarrow \mathrm{G}$ (Ser/Cys) & 29.9 \\
PARP1 & 762 & $\mathrm{~T} \rightarrow \mathrm{C}$ (Val/Ala) & 24.4 \\
PARP4 & 1,280 & $\mathrm{G} \rightarrow \mathrm{C}$ (Gly/Arg) & 45.8 \\
& 1,328 & $\mathrm{C} \rightarrow \mathrm{A}$ (Pro/Thr) & 45.8 \\
XRCC1 & 194 & $\mathrm{C} \rightarrow \mathrm{T}$ (Arg/Trp) & 13.1 \\
& 399 & $\mathrm{G} \rightarrow \mathrm{A}($ Arg/Gln) & 26.6 \\
\hline
\end{tabular}

${ }^{a}$ According to http://www.ncbi.nlm.nih.gov/snp/. MAF, minor allele frequency; APEX1, apurinic/apyrimidinic endonuclease 1; MUTYH, mutY DNA glycosylase, earlier mutY homolog (E. coli); OGG1, 8-oxoguanine DNA glycosylase 1; PARP, poly (ADP-ribose) polymerase; XRCC1, X-ray repair cross-complementing 1.

alcohol consumption was significantly increased in patients compared with that in controls $(\mathrm{P}<0.0001)$ (Table I).

SNPs genotyping. Of the eight SNPs included in the study, only seven were completely genotyped (Table III), since both SNPs of the PARP4 gene were in linkage disequilibrium $\left(\mathrm{r}^{2}>0.80\right)$, thus behaving as tag SNPs.

The genotype frequencies determined for all polymorphisms under study are shown in Table IV. When considered individually, no correlation between polymorphisms of the BER pathway genes and individual susceptibility to PN-MPNs as a whole could be identified. All the SNPs studied were in agreement with the Hardy-Weinberg law ( $\mathrm{P}>0.05$, exact probability test), with the exception of PARPI Val762Ala ( $\mathrm{P}=0.029$, exact probability test).

The genotypic frequencies obtained in the control populations are similar to those reported previously in other Caucasian populations $(33,34,40,45)$.

As shown in Table IV, no significant differences in genotypic frequencies were observed for any of the seven polymorphisms between cases and controls as a whole $\left(\mathrm{P}>0.05, \chi^{2}\right.$ test). However, when the population was stratified for pathology status, gender and presence of JAK2 mutation, a tendency for decrease risk was noticed for MUTYH Gln335His and XRCC1 Gln399Arg polymorphisms (Table V).

Upon stratification for pathology status, the results revealed that, for ET, the presence of at least one variant allele for the XRCC1 Gln399Arg gene polymorphism displayed a borderline effect on the population (crude OR, 0.623; 95\% CI, 0.378-1.028; $\mathrm{P}=0.069$ ) (Table V).

The results demonstrated a decreased risk in the female group with ET diagnosis and with at least one variant allele for MUTYH Gln335His gene polymorphism (OR, 0.478; 95\% CI, 0.238-0.962) upon adjustment for potential risk factors (Table V).
The relevance of JAK2 mutation in PN-MPNs is well known (3-5,7). Therefore, the population was also stratified according to the presence of $J A K 2$ mutation in patients, showing that the presence of at least one variant allele for XRCC1 Gln399Arg gene polymorphism constitutes a decreased risk for ET patients (OR, 0.500; 95\% CI, 0.278-0.896) (Table V).

Overall, the results indicate that only XRCC1 Gln399Arg and MUTYH Gln335His gene polymorphisms appeared to be associated with PN-MPNs risk. For the remaining polymorphisms under study, no significant changes in crude or adjusted OR were observed (Tables IV and V).

Haplogroup association. A key point that should be explored in studies such as the present one is the effect of the combination of all genotypes, since the real situation is the effect of the variants altogether. The results provided by the SNPstat software yielded 60 different combinations, the most frequent of which are shown in Table VI. Analyzing the results as haplogroup association response, an increased risk to develop a MPN was obtained for one specific combination (OR, 3.91; 95\% CI, 1.02-14.95) (Table VII).

\section{Discussion}

DNA repair deficiencies and genetic or epigenetic changes may decrease the efficiency of DNA repair, thus contributing to individual susceptibility to DNA damaging agents and to cancer risk (46-48). However, to the best of our knowledge, no clinical association studies have been performed to evaluate the role of BER pathway polymorphisms on PN-MPNs susceptibility.

The present study revealed a higher incidence of $J A K 2$ V617F mutation in ET patients and a lower incidence in PV patients, compared with that reported in the literature $(12,13)$. This finding is probably due to the small population studied and to the fact that ET was the most frequent diagnosis among the patients included in the current case group.

The present study was intended to ascertain the possible role of the genetic polymorphisms APEX1 Asp148Glu, MUTYH Gln335His, OGG1 Ser326Cys, PARP1 Val762Ala, PARP4 Gly1280Arg, and XRCC1 Arg194Trp and Arg399Gln on the individual susceptibility for PN-MPNs. The genotypic frequencies of the different SNPs in the control population are similar to those reported in other Caucasian populations $(33,34,40)$.

The MUTYH protein acts as a BER glycosylase and is mainly involved in the repair of oxidative DNA lesions (34,40,46,49-56). MUTYH dysfunction may therefore be of special relevance in human tumourigenesis, since it is the only mechanism for repairing 8-oxo-dG/adenine mismatches (49). Indeed, two specific germline mutations in this gene, Tyr165Cys and Gly382Asp, have been associated with a colorectal adenoma and carcinoma predisposition syndrome that is now referred to as MUTYH-associated polyposis (49). However, various others mutations and SNPs have been described to date, for which a specific phenotypic consequence is unknown (49). An example of one common SNP in the MUTYH gene is the nonsynonymous Gln335His variation in codon 12 (49,50). The enzyme encoded by this variant has been demonstrated to have partially impaired glycosylase activity in vitro, and could therefore contribute to cancer susceptibility, being much more 
Table IV. Genotype distribution and myeloproliferative risk for the APEX1 Asp148Glu, MUTYH Gln335His, OGG1 Ser326Cys, PARP1 Val762Ala, PARP4 Gly1280Arg, and XRCC1 Gln399Arg and Arg194Trp polymorphisms in the myeloproliferative neoplasms case $(n=133)$ and control $(n=281)$ populations.

\begin{tabular}{|c|c|c|c|c|c|}
\hline Genetic polymorphism & Controls, n (\%) & Cases, n (\%) & P-value & OR crude $(95 \% \mathrm{CI})$ & OR adjusted $(95 \% \mathrm{CI})^{\mathrm{b}}$ \\
\hline APEX1 (Asp148Glu) & & & 0.952 & & \\
\hline Asp/Asp & $73(26.4)$ & $37(27.8)$ & & 1.000 (Reference) & 1.000 (Reference) \\
\hline Asp/Glu & $136(49.1)$ & $64(48.1)$ & & $0.928(0.566-1.523)$ & $0.963(0.580-1.599)$ \\
\hline Glu/Glu & $68(24.5)$ & $32(24.1)$ & & $0.928(0.521-1.653)$ & $0.923(0.512-1.663)$ \\
\hline Asp/Glu+Glu/Glu & 204 (73.6) & $96(72.2)$ & & $0.928(0.584-1.477)$ & $0.949(0.591-1.526)$ \\
\hline MUTYH (Gln335His) & & & 0.877 & & \\
\hline His/His & $142(51.3)$ & $68(51.1)$ & & 1.000 (Reference) & 1.000 (Reference) \\
\hline His/Gln & $112(40.4)$ & $52(39.1)$ & & $0.970(0.626-1.502)$ & $0.902(0.550-1.413)$ \\
\hline Gln/Gln & $23(8.3)$ & $13(9.8)$ & & $1.180(0.654-2.471)$ & $1.075(0.506-2.283)$ \\
\hline His/Gln+Gln/Gln & $135(48.7)$ & $65(48.9)$ & & $1.005(0.665-1.521)$ & $0.932(0.609-1.425)$ \\
\hline OGG1 (Ser326Cys) & & & 0.545 & & \\
\hline Ser/Ser & $182(65.7)$ & $83(62.6)$ & & 1.000 (Reference) & 1.000 (Reference) \\
\hline Ser/Cys & $83(30.0)$ & $41(30.8)$ & & $1.083(0.687-1.708)$ & $1.075(0.672-1.720)$ \\
\hline Cys/Cys & $12(4.3)$ & $9(6.8)$ & & $1.645(0.667-4.055)$ & $1.603(0.631-4.072)$ \\
\hline Ser/Cys+Cys/Cys & $95(34.3)$ & $50(37.6)$ & & $1.154(0.751-1.774)$ & $1.144(0.735-1.781)$ \\
\hline PARP1 (Val762Ala) & & & 0.769 & & \\
\hline $\mathrm{Val} / \mathrm{Val}$ & $214(77.0)$ & $104(78.2)$ & & 1.000 (Reference) & 1.000 (Reference) \\
\hline $\mathrm{Val} / \mathrm{Ala}$ & $63(22.7)$ & $29(21.8)$ & & $0.947(0.575-1.559)$ & $1.019(0.607-1.712)$ \\
\hline Ala/Ala & $1(0.4)$ & $0(0.0)$ & & ND & ND \\
\hline Val/Ala+Ala/Ala & $64(23.0)$ & $29(21.8)$ & & $0.932(0.567-1.533)$ & $1.000(0.596-1.677)$ \\
\hline PARP4 (Gly1280Arg) & & & 0.593 & & \\
\hline Gly/Gly & $105(37.9)$ & $54(40.6)$ & & 1.000 (Reference) & 1.000 (Reference) \\
\hline Gly/Arg & $141(50.9)$ & $61(45.9)$ & & $0.841(0.539-1.313)$ & $0.806(0.510-1.273)$ \\
\hline Arg/Arg & $31(11.2)$ & $18(13.5)$ & & $1.129(0.579-2.200)$ & $1.000(0.501-1.997)$ \\
\hline Gly/Arg+Arg/Arg & $172(62.9)$ & $79(59.4)$ & & $0.893(0.585-1.363)$ & $0.841(0.543-1.301)$ \\
\hline XRCC1 (Arg 194Trp) & & & 0.263 & & \\
\hline Arg/Arg & $236(85.5)$ & $121(91.0)$ & & 1.000 (Reference) & 1.000 (Reference) \\
\hline Arg/Trp & $39(14.1)$ & $12(9.0)$ & & $0.600(0.303-1.188)$ & $0.650(0.323-1.307)$ \\
\hline $\operatorname{Trp} / \operatorname{Trp}$ & $1(0.4)$ & $0(0.0)$ & & ND & ND \\
\hline Arg/Trp+Trp/Trp & $40(14.5)$ & $12(9.0)$ & & $0.585(0.296-1.156)$ & $0.633(0.315-1.270)$ \\
\hline XRCC1 (Gln399Arg) & & & 0.318 & & \\
\hline Arg/Arg & $113(40.8)$ & $61(45.9)$ & & 1.000 (Reference) & 1.000 (Reference) \\
\hline Arg/Gln & $134(48.4)$ & $54(40.6)$ & & $0.747(0.479-1.163)$ & $0.762(0.483-1.204)$ \\
\hline $\mathrm{G} \ln / \mathrm{G} \ln$ & $30(10.8)$ & $18(13.5)$ & & $1.111(0.573-2.155)$ & $1.044(0.531-2.052)$ \\
\hline $\mathrm{Arg} / \mathrm{Gln}+\mathrm{Gln} / \mathrm{Gln}$ & $164(59.2)$ & $72(54.1)$ & & $0.813(0.536-1.234)$ & $0.818(0.532-1.255)$ \\
\hline
\end{tabular}

${ }^{\text {aP }}$-value determined by $\chi^{2}$ test. ${ }^{\mathrm{b}} \mathrm{ORs}$ were adjusted for age $(30-49,50-69$ and $>70$ years), tobacco smoking status (never or former and current) and alcohol consumption (never, social and regular drinkers). APEX1, apurinic/apyrimidinic endonuclease 1; MUTYH, mutY DNA glycosylase, earlier mutY homolog (E. coli); OGG1, 8-oxoguanine DNA glycosylase 1; PARP, poly (ADP-ribose) polymerase; XRCC1, X-ray repair cross-complementing 1; OR, odds ratio; CI, confidence interval; ND, none determined.

frequently detected in Japanese and Chinese populations than in European populations (34,52). The Gln335His variant allele has been suggested to be associated with increased risk of colorectal cancer $(50,52,57)$ and less consistently with lung cancer (53). For the latter, however, existing evidence is conflicting or significant only when taking into account gene-gene interactions (53). Notably, an almost significant decrease in breast cancer risk (OR, 0.80; 95\% CI, 0.59-1.07) was described previously by our group in MUTYH Gln335His heterozygotes (40). Furthermore, gene-gene interactions among BER polymorphisms were observed in ever tobacco smokers in a bladder cancer susceptibility study (54). Those previous results suggest that genetic variation in BER genes may contribute to cancer risk through gene-gene and gene-environmental interactions.

To the best of our knowledge, there are no clinical association studies in which the role of the MUTYH Gln335His 
Table V. ORs (95\% CI) for MUTYH (Gln335His) and XRCC1_399 (Gln399Arg) polymorphisms and Philadelphia-negative myeloproliferative neoplasms association.

\begin{tabular}{|c|c|c|c|c|c|}
\hline Pathology stratification & Patients, $\mathrm{n}$ & SNP & P-value ${ }^{a}$ & OR crude $(95 \% \mathrm{CI})$ & OR adjusted $(95 \% \mathrm{CI})^{\mathrm{b}}$ \\
\hline \multirow[t]{5}{*}{ ET } & 80 & $\begin{array}{c}\text { XRCC1_399 } \\
\text { (Gln399Arg; rs25487) }\end{array}$ & 0.166 & & \\
\hline & & Arg/Arg & & 1.000 (Reference) & 1.000 (Reference) \\
\hline & & $\mathrm{Arg} / \mathrm{Gln}$ & & $0.602(0.354-1.025)^{\mathrm{i}}$ & $0.611(0.355-1.053)^{\mathrm{i}}$ \\
\hline & & Gln/Gln & & $0.717(0.305-1.690)$ & $0.667(0.279-1.595)$ \\
\hline & & $\mathrm{Arg} / \mathrm{Gln}+\mathrm{Gln} / \mathrm{Gln}$ & & $0.623(0.378-1.028)^{\mathrm{i}}$ & $0.622(0.373-1.038)^{\mathrm{i}}$ \\
\hline \multirow[t]{5}{*}{ ET, females } & 48 & $\begin{array}{c}\text { MUTYH } \\
\text { (Gln335His; rs3219489) }\end{array}$ & 0.015 & & \\
\hline & & His/His & & 1.000 (Reference) & 1.000 (Reference) \\
\hline & & His/Gln & & $0.342(0.152-0.773)^{\mathrm{c}}$ & $0.325(0.142-0.744)^{\mathrm{d}}$ \\
\hline & & Gln/Gln & & $1.331(0.480-3.692)$ & $1.229(0.435-3.475)$ \\
\hline & & His/Gln+Gln/Gln & & $0.507(0.256-1.003)^{\mathrm{i}}$ & $0.478(0.238-0.962)^{\mathrm{j}}$ \\
\hline \multirow[t]{5}{*}{ ET, JAK2 } & 58 & $\begin{array}{c}\text { XRCC1_399 } \\
\text { (Gln399Arg; rs25487) }\end{array}$ & 0.044 & & \\
\hline & & Arg/Arg & & 1.000 (Reference) & 1.000 (Reference) \\
\hline & & $\mathrm{Arg} / \mathrm{Gln}$ & & $0.471(0.255-0.871)^{\mathrm{e}}$ & $0.490(0.263-0.915)^{\mathrm{f}}$ \\
\hline & & Gln/Gln & & $0.554(0.199-1.538)$ & $0.539(0.192-1.514)$ \\
\hline & & $\mathrm{Arg} / \mathrm{Gln}+\mathrm{Gln} / \mathrm{Gln}$ & & $0.486(0.274-0.864)^{\mathrm{g}}$ & $0.500(0.278-0.896)^{\mathrm{h}}$ \\
\hline \multicolumn{6}{|c|}{ 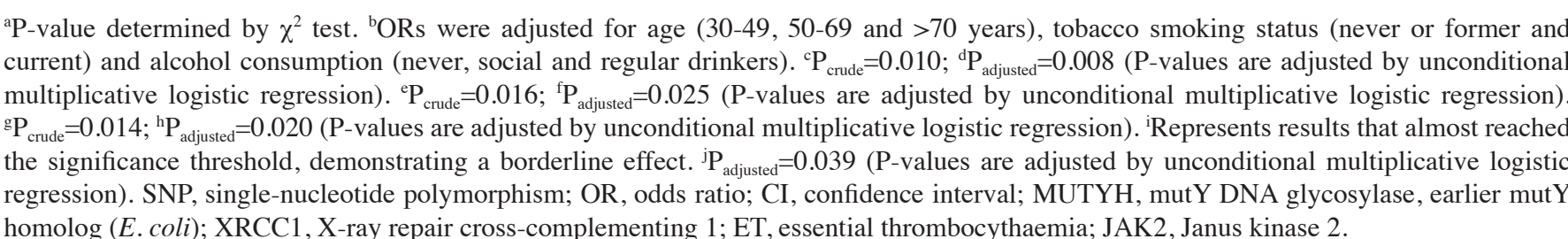 } \\
\hline
\end{tabular}

Table VI. Haplogroup frequencies for the single-nucleotide polymorphisms under study.

\begin{tabular}{|c|c|c|c|c|c|c|c|c|c|}
\hline \multicolumn{7}{|c|}{ Haplogroup estimation } & \multirow[b]{2}{*}{$\begin{array}{l}\text { Global } \\
\text { frequency }\end{array}$} & \multicolumn{2}{|c|}{$\begin{array}{l}\text { Haplogroup } \\
\text { frequencies }\end{array}$} \\
\hline $\begin{array}{l}\text { APEX } \\
\text { D148E }\end{array}$ & $\begin{array}{c}M U T Y H \\
\text { Q335H }\end{array}$ & $\begin{array}{l}\text { OGG1 } \\
\text { S326C }\end{array}$ & $\begin{array}{l}\text { PARP1 } \\
\text { V762A }\end{array}$ & $\begin{array}{c}\text { PARP4 } \\
\text { G1,280R }\end{array}$ & $\begin{array}{c}\text { XRCC1_194 } \\
\text { R194W }\end{array}$ & $\begin{array}{c}\text { XRCC1_399 } \\
\text { R399Q }\end{array}$ & & Controls & $\overline{\text { Cases }}$ \\
\hline D & $\mathrm{H}$ & $\mathrm{S}$ & V & G & $\mathrm{R}$ & $\mathrm{R}$ & 0.116 & 0.167 & 0.068 \\
\hline E & $\mathrm{H}$ & S & V & G & $\mathrm{R}$ & $\mathrm{R}$ & 0.084 & 0.060 & 0.130 \\
\hline $\mathrm{E}$ & $\mathrm{H}$ & S & V & G & $\mathrm{R}$ & Q & 0.069 & 0.065 & 0.062 \\
\hline E & $\mathrm{H}$ & $\mathrm{S}$ & V & $\mathrm{R}$ & $\mathrm{R}$ & $\mathrm{R}$ & 0.050 & 0.058 & 0.044 \\
\hline $\mathrm{D}$ & $\mathrm{H}$ & S & $\mathrm{V}$ & $\mathrm{R}$ & $\mathrm{R}$ & Q & 0.045 & 0.036 & 0.060 \\
\hline $\mathrm{D}$ & $\mathrm{H}$ & $\mathrm{S}$ & $\mathrm{V}$ & $\mathrm{R}$ & $\mathrm{R}$ & $\mathrm{R}$ & 0.045 & 0.030 & 0.060 \\
\hline $\mathrm{E}$ & $\mathrm{H}$ & $\mathrm{C}$ & $\mathrm{V}$ & G & $\mathrm{R}$ & $\mathrm{R}$ & 0.033 & 0.025 & 0.042 \\
\hline $\mathrm{E}$ & Q & S & $\mathrm{V}$ & $\mathrm{R}$ & $\mathrm{R}$ & $\mathrm{R}$ & 0.032 & 0.028 & 0.053 \\
\hline
\end{tabular}

APEX1, apurinic/apyrimidinic endonuclease 1; MUTYH, mutY DNA glycosylase, earlier mutY homolog (E.coli); OGG1,8-oxoguanine DNA glycosylase 1; PARP, poly (ADP-ribose) polymerase; XRCC1, X-ray repair cross-complementing 1.

polymorphism had been evaluated on PN-MPNs susceptibility. The results reported in the present study suggest that, when considering females with ET, a consistent decrease in overall PN-MPNs risk was observed when at least one variant allele carrying MUTYH Gln335His is present (Table V).
The XRCC1 nuclear protein serves an important role in assisting and enabling the repair of single-strand breaks by interacting and recruiting to the DNA lesion sites multiple enzymatic components of repair reactions (58). Arg194Trp and Arg399Gln polymorphisms are among the most extensively 
Table VII. Haplogroup association response for the single-nucleotide polymorphisms under study.

\begin{tabular}{|c|c|c|c|c|c|c|c|c|}
\hline \multicolumn{7}{|c|}{ Haplotype association response } & \multirow[b]{2}{*}{ OR $(95 \% \mathrm{CI})$} & \multirow[b]{2}{*}{ P-value } \\
\hline $\begin{array}{l}A P E X \\
\text { D148E }\end{array}$ & $\begin{array}{c}\text { MUTYH } \\
\text { Q335H }\end{array}$ & $\begin{array}{l}O G G 1 \\
\text { S326C }\end{array}$ & $\begin{array}{l}\text { PARP1 } \\
\text { V762A }\end{array}$ & $\begin{array}{c}\text { PARP4 } \\
\text { G1280R }\end{array}$ & $\begin{array}{c}\text { XRCC1_194 } \\
\text { R194W }\end{array}$ & $\begin{array}{c}\text { XRCC1_399 } \\
\text { R399Q }\end{array}$ & & \\
\hline $\mathrm{D}$ & $\mathrm{H}$ & $\mathrm{S}$ & $\mathrm{V}$ & $\mathrm{G}$ & $\mathrm{R}$ & $\mathrm{R}$ & 1.00 (Reference) & \\
\hline $\mathrm{E}$ & $\mathrm{H}$ & $\mathrm{S}$ & $\mathrm{V}$ & $\mathrm{G}$ & $\mathrm{R}$ & $\mathrm{R}$ & $3.17(0.99-10.17)$ & 0.05 \\
\hline $\mathrm{E}$ & $\mathrm{H}$ & $\mathrm{S}$ & $\mathrm{V}$ & $\mathrm{G}$ & $\mathrm{R}$ & Q & $0.92(0.34-2.53)$ & 0.88 \\
\hline $\mathrm{E}$ & $\mathrm{H}$ & $\mathrm{S}$ & $\mathrm{V}$ & $\mathrm{R}$ & $\mathrm{R}$ & $\mathrm{R}$ & $1.55(0.50-4.76)$ & 0.45 \\
\hline $\mathrm{D}$ & $\mathrm{H}$ & $\mathrm{S}$ & V & $\mathrm{R}$ & $\mathrm{R}$ & Q & $2.13(0.60-7.53)$ & 0.24 \\
\hline $\mathrm{D}$ & $\mathrm{H}$ & $\mathrm{S}$ & V & $\mathrm{R}$ & $\mathrm{R}$ & $\mathrm{R}$ & $1.90(0.41-8.79)$ & 0.41 \\
\hline $\mathrm{E}$ & $\mathrm{H}$ & $\mathrm{C}$ & $\mathrm{V}$ & $\mathrm{G}$ & $\mathrm{R}$ & $\mathrm{R}$ & $3.41(0.87-13.36)$ & 0.08 \\
\hline $\mathrm{E}$ & Q & $\mathrm{S}$ & $\mathrm{V}$ & $\mathrm{R}$ & $\mathrm{R}$ & $\mathrm{R}$ & $3.91(1.02-14.95)$ & $0.05^{\mathrm{a}}$ \\
\hline
\end{tabular}

APEX1, apurinic/apyrimidinic endonuclease 1; MUTYH, mutY DNA glycosylase, earlier mutY homolog (E. coli); OGG1, 8-oxoguanine DNA glycosylase 1; PARP, poly (ADP-ribose) polymerase; XRCC1, X-ray repair cross-complementing 1; OR, odds ratio; CI, confidence interval. ${ }^{\mathrm{a}} \mathrm{P}<0.047$.

studied SNPs in the XRCC1 gene $(25,29,30,33-35,37,46,51$, 53-55,59-63). These two SNPs have been shown to alter the functional activity of the resulting protein in vitro and to interfere with cancer susceptibility. The Arg194Trp variant allele has been associated with decreased risk of certain cancers, particularly among tobacco smokers (59). Conversely, the Arg399Gln variant allele has been suggested to be associated with decreased DNA repair capacity and higher sensitivity to genotoxicants compared with the Arg194Trp variant allele (64). However, previous epidemiological results have been inconsistent and dependent on the cancer type $(51,65,66)$. Several interactions such as gene-environment (e.g. alcohol consumption or menopausal age) and gene-gene (e.g. other DNA repair or chemical metabolizing enzymes) have also been reported for both SNPs (46). However, several well-powered studies and meta-analyses have not confirmed these supposed effects $(46,60)$. Generally, the results reported to date suggest a modest impact of both $X R C C 1$ gene polymorphisms on protein activity and cancer susceptibility. However, certain studies have suggested that they may represent a risk factor for haematological malignancies such as leukaemia, according to previous studies on XRCC1 polymorphisms in association with AML, acute lymphoblastic leukaemia, chronic lymphocytic leukaemia and lymphoma $(25,29,30)$. The present results support a borderline effect for ET patients and a protective effect in overall PN-MPNs risk when considering ET patients presenting JAK2 mutation, as observed under the presence of at least one variant allele carrying XRCC1 Arg399Gln (Table V). Although the Arg194Trp allele did not show any association with the risk of developing PN-MPNs, it should be noted that the Arg194Trp variant allele may be associated with higher DNA repair capacity, lower sensitivity to gentoxicants and decreased risk of other cancers, when compared with other variants. In addition, other factors may influence the biological effect of the Arg194Trp polymorphism, such as disease development stage, specific environmental factors and even different genetic background among populations.
In order to clarify the role of XRCC1 polymorphisms in PN-MPNs susceptibility, larger studies and/or a meta-analysis are required.

Regarding the OGG1 Ser326Cys polymorphism, the current results did not reveal a significant contribution on individual susceptibility towards PN-MPNs (Tables III and IV). The OGG1 Ser326Cys polymorphism has been demonstrated to impair protein function (46), and therefore, it has been widely evaluated in different case-control studies (67). Significant results were observed in lung $(59,68)$, head and neck $(69,70)$, colorectal $(51,71)$ and gallbladder cancer $(65,72)$. However, several previous meta-analyses (68,70,73-76) did not reveal any significant association between this $O G G 1$ polymorphism and other cancers risk.

Human APEX1 is a multifunctional enzyme that holds complementary key roles in cancer. Notably, this enzyme is a crucial component of the BER pathway due to its ability to process AP sites and other 3'DNA termini that may result, for example, from exposure to ionizing radiation or direct attack by free radicals $(59,77,78)$. Among the 18 identified SNPs for the APEXI gene, the most studied one is the $\mathrm{T}>\mathrm{G}$ transition at codon 148 of exon 5, which leads to a change in amino acid from Asp to Glu (56). Its potential role on cancer was evaluated in four meta-analyses on breast cancer susceptibility $(55,79-81)$, two meta-analyses on prostate cancer $(82,83)$ and several studies on other types of cancer (84-87). However, the results published remain inconclusive. Concerning the present results, the association of APEX1 Asp148Glu with PN-MPNs risk did not exhibit any association.

PARP1 is an abundant nuclear protein that can bind to DNA and promote the poly (ADP-ribosylation) of a variety of proteins. PARP1 acts on single- and double-stranded DNA breaks by recruiting DNA repair factors (88). It has a major signaling role in DNA damage detection and repair, acting as a molecular nick sensor to initiate the recruitment of XRCC1 and the assembly of the single-strand break repair machinery (89). PARPI Val762Ala is one of the most common nonsynonymous SNPs studied in this gene, resulting in an amino acid 
substitution within the $\mathrm{COOH}$-terminal catalytic domain of the enzyme $(90,91)$. This variant has been associated with reduced enzymatic activity (61) and limited capacity for interaction with $X R C C 1$ (62). This may result in decreased BER capacity, thus increasing cancer predisposition in PARPI Val762Ala carriers. Indeed, this variant form has been associated in various well-powered clinical association studies with increased cancer susceptibility, namely to lung (61) and gastrointestinal tract $(62,92)$ cancer, while Adel Fahmideh et al (74) described a decreased risk for glioma associated with this SNP. Studies regarding other types of cancer such as breast cancer $(55,63)$ failed to demonstrate an association between PARPI Val762Ala and cancer susceptibility. The present results do not suggest any association between PARPI Val762Ala polymorphism and PN-MPNs risk (Table IV).

Concerning the analysis of haplogroups' association response, an increased risk to PN-MPNs could be observed for one specific combination (Table VII). This result should, however, be taken with care when evaluating this parameter risk for PN-MPNs due to its low frequency (3.2\%) in the studied population, even though it may represent a tendency on how SNPs in BER genes influence PN-MPNs.

Overall, the present results reveal that the $\mathrm{XRCCl}$ Gln399Arg and MUTYH Gln335His gene polymorphisms appear to be associated with PN-MPNs risk. For all other polymorphisms under study, no significant change was observed (Tables IV and V).

Although certain published studies consider tobacco smoking as a contributing factor for PN-MPNs $(93,94)$, the present study did not reveal an important association, probably due to the small number of tobacco smokers included.

Additional studies involving larger populations should be conducted to further clarify the potential value of the different BER genotypes as predictive biomarkers of susceptibility to PN-MPNs and to study gene-environment and gene-gene interactions. In addition, stratified analysis according to histological subtype and disease stage should be conducted.

\section{Acknowledgements}

The authors gratefully acknowledge all patients and controls who generously participated in the present study. Our appreciation and thanks are extended to laboratory technicians, Mrs. Luísa Manso Oliveira, Mrs. Sílvia Morgado Amaro and Miss Inês Sousa, (Department of Clinical Pathology, Hospital de São Francisco Xavier, Centro Hospitalar de Lisboa Ocidental) for their expert technical assistance. The present study was supported by funding through the project no. UID/BIM/00009/2013 from the Science and Technology Foundation of Portugal, which also awarded a Post-Doctoral Research grant to S.N.S. (grant no. SFRH/BPD/80462/2011).

\section{References}

1. Swerdlow SH, Campo E, Harris NL, Jaffe ES, Pileri SA, Stein H, Thiele J and Vardiman JW (eds): WHO Classification of Tumours of Haematopoietic and Lymphoid Tissues, Fourth Edition. IARC Press, Lyon, 2008.

2. Arber DA, Orazi A, Hasserjian R, Thiele J, Borowitz MJ, Le Beau MM, Bloomfield CD, Cazzola M and Vardiman JW: The 2016 revision to the world health organization classification of myeloid neoplasms and acute leukemia. Blood 127: 2391-2405, 2016.
3. James C,Ugo V,LeCouédic JP,Staerk J,Delhommeau F,LacoutC, Garçon L, Raslova H, Berger R, Bennaceur-Griscelli A, et al: A unique clonal JAK2 mutation leading to constitutive signalling causes polycythaemia vera. Nature 434: 1144-1148, 2005.

4. Kralovics R, Passamonti F, Buser AS, Teo SS, Tiedt R, Passweg JR, Tichelli A, Cazzola M and Skoda RC: A gain-of-function mutation of JAK2 in myeloproliferative disorders. N Engl J Med 352: 1779-1790, 2005.

5. Levine RL, Wadleigh M, Cools J, Ebert BL, Wernig G, Huntly BJ, Boggon TJ, Wlodarska I, Clark JJ, Moore S, et al: Activating mutation in the tyrosine kinase JAK2 in polycythemia vera, essential thrombocythemia, and myeloid metaplasia with myelofibrosis. Cancer Cell 7: 387-397, 2005.

6. Baxter EJ, Scott LM, Campbell PJ, East C, Fourouclas N, Swanton S, Vassiliou GS, Bench AJ, Boyd EM, Curtin N, et al: Acquired mutation of the tyrosine kinase JAK2 in human myeloproliferative disorders. Lancet 365: 1054-1061, 2005.

7. Scott LM, Tong W, Levine RL, Scott MA, Beer PA, Stratton MR, Futreal PA, Erber WN, McMullin MF, Harrison CN, et al: JAK2 exon 12 mutations in polycythemia vera and idiopathic erythrocytosis. N Engl J Med 356: 459-468, 2007.

8. Chi J, Manoloukos M, Pierides C, Nicolaidou V, Nicolaou K, Kleopa M, Vassiliou G and Costeas P: Calreticulin mutations in myeloproliferative neoplasms and new methodology for their detection and monitoring. Ann Hematol 94: 399-408, 2015.

9. Ha JS and Kim YK: Calreticulin exon 9 mutations in myeloproliferative neoplasms. Ann Lab Med 35: 22-27, 2015.

10. Klampfl T, Gisslinger H, Harutyunyan AS, Nivarthi H, Rumi E, Milosevic JD, Them NC, Berg T, Gisslinger B, Pietra D, et al: Somatic mutations of calreticulin in myeloproliferative neoplasms. N Engl J Med 369: 2379-2390, 2013.

11. Rumi E, Pietra D, Ferretti V, Klampfl T, Harutyunyan AS, Milosevic JD, Them NC, Berg T, Elena C, Casetti IC, et al: JAK2 or CALR mutation status defines subtypes of essential thrombocythemia with substantially different clinical course and outcomes. Blood 123: 1544-1551, 2014.

12. Tefferi A and Pardanani A: Myeloproliferative neoplasms: A contemporary review. JAMA Oncol 1: 97-105, 2015.

13. Nangalia J, Massie CE, Baxter EJ, Nice FL, Gundem G, Wedge DC, Avezov E, Li J, Kollmann K, Kent DG, et al: Somatic CALR mutations in myeloproliferative neoplasms with nonmutated JAK2. N Engl J Med 369: 2391-2405, 2013.

14. Delhommeau F, Jeziorowska D, Marzac C and Casadevall N: Molecular aspects of myeloproliferative neoplasms. Int J Hematol 91: 165-173, 2010.

15. Levine RL: Mechanisms of mutations in myeloproliferative neoplasms. Best Pract Res Clin Haematol 22: 489-494, 2009.

16. Campregher PV, Santos FP, Perini GF and Hamerschlak N: Molecular biology of Philadelphia-negative myeloproliferative neoplasms. Rev Bras Hematol Hemoter 34: 150-155, 2012.

17. Rueff J and Rodrigues AS: Cancer drug resistance: A brief overview from a genetic viewpoint. Methods Mol Biol 1395: $1-18,2016$.

18. Mesa R, Miller CB, Thyne M, Mangan J, Goldberger S, Fazal S, Ma X, Wilson W, Paranagama DC, Dubinski DG, et al: Myeloproliferative neoplasms (MPNs) have a significant impact on patients' overall health and productivity: The MPN landmark survey. BMC Cancer 16: 167, 2016.

19. Passamonti F, Rumi E, Pungolino E, Malabarba L, Bertazzoni $P$, Valentini M, Orlandi E, Arcaini L, Brusamolino E, Pascutto C, et al: Life expectancy and prognostic factors for survival in patients with polycythemia vera and essential thrombocythemia. Am J Med 117: 755-761, 2004.

20. Wolanskyj AP, Schwager SM, McClure RF, Larson DR and Tefferi A: Essential thrombocythemia beyond the first decade: Life expectancy, long-term complication rates, and prognostic factors. Mayo Clin Proc 81: 159-166, 2006.

21. Björkholm M, Hultcrantz $M$ and Derolf ÅR: Leukemic transformation in myeloproliferative neoplasms: Therapy-related or unrelated? Best Pract Res Clin Haematol 27: 141-153, 2014.

22. Rampal R, Ahn J, Abdel-Wahab O, Nahas M, Wang K, Lipson D, Otto GA, Yelensky R, Hricik T, McKenney AS, et al: Genomic and functional analysis of leukemic transformation of myeloproliferative neoplasms. Proc Natl Acad Sci USA 111: E5401-E5410, 2014.

23. Björkholm M, Hultcrantz M and Derolf ÅR: Leukemic transformation in myeloproliferative neoplasms: Therapy-related or unrelated? Best Pract Res Clin Haematol 27: 141-153, 2014. 
24. Hernández-Boluda JC, Pereira A, Cervantes F, Alvarez-Larrán A, Collado M, Such E, Arilla MJ, Boqué C, Xicoy B, Maffioli M, et al: A polymorphism in the XPD gene predisposes to leukemic transformation and new nonmyeloid malignancies in essential thrombocythemia and polycythemia vera. Blood 119: 5221-5228, 2012.

25. Bolufer P, Barragan E, Collado M, Cervera J, López JA and Sanz MA: Influence of genetic polymorphisms on the risk of developing leukemia and on disease progression. Leuk Res 30: 1471-1491, 2006.

26. Beer PA, Delhommeau F, LeCouédic JP, Dawson MA, Chen E, Bareford D, Kusec R, McMullin MF, Harrison CN, Vannucchi AM, et al: Two routes to leukemic transformation after a JAK2 mutation-positive myeloproliferative neoplasm. Blood 115: 2891-2900, 2010

27. Hasselbalch HC, Thomassen M, Riley CH, Kjær L, Larsen TS Jensen MK, Bjerrum OW, Kruse TA and Skov V: Whole blood transcriptional profiling reveals deregulation of oxidative and antioxidative defence genes in myelofibrosis and related neoplasms. Potential implications of downregulation of Nrf2 for genomic instability and disease progression. PLoS One 9: e112786, 2014

28. Kilpivaara O and Levine RL: JAK2 and MPL mutations in myeloproliferative neoplasms: Discovery and science. Leukemia 22: 1813-1817, 2008.

29. Batar B, Güven M, Bariș S, Celkan T and Yildiz I: DNA repair gene XPD and XRCC1 polymorphisms and the risk of childhood acute lymphoblastic leukemia. Leuk Res 33: 759-763, 2009.

30. Bănescu C, Trifa AP, Demian S, Benedek Lazar E, Dima D, Duicu C and Dobreanu M: Polymorphism of XRCC1, XRCC3, and XPD genes and risk of chronic myeloid leukemia. Biomed Res Int 2014: 213790, 2014.

31. Hoeijmakers JH: Genome maintenance mechanisms for preventing cancer. Nature 411: 366-374, 2001.

32. Wang CQ, Krishnan V, Tay LS, Chin DW, Koh CP, Chooi JY, Nah GS, Du L, Jacob B, Yamashita N, et al: Disruption of Runx1 and Runx3 leads to bone marrow failure and leukemia predisposition due to transcriptional and DNA repair defects. Cell Rep 8: 767-782, 2014

33. Silva SN, Moita R, Azevedo AP, Gouveia R, Manita I, Pina JE, Rueff J and Gaspar J: Menopausal age and XRCC1 gene polymorphisms: Role in breast cancer risk. Cancer Detect Prev 31: 303-309, 2007.

34. Santos LS, Branco SC, Silva SN, Azevedo AP, Gil OM, Manita I, Ferreira TC, Limbert E, Rueff J and Gaspar JF: Polymorphisms in base excision repair genes and thyroid cancer risk. Oncol Rep 28: 1859-1868, 2012.

35. Yan L, Li Q, Li X, Ji H and Zhang L: Association studies between XRCC1, XRCC2, XRCC3 polymorphisms and differentiated thyroid carcinoma. Cell Physiol Biochem 38: 1075-1084, 2016.

36. Baute $J$ and Depicker A: Base excision repair and its role in maintaining genome stability. Crit Rev Biochem Mol Biol 43: 239-276, 2008

37. Annamaneni S, Gorre M, Kagita S, Addepalli K, Digumarti RR, Satti V and Battini MR: Association of XRCC1 gene polymorphisms with chronic myeloid leukemia in the population of Andhra Pradesh, India. Hematology 18: 163-168, 2013.

38. Tefferi A and Vardiman JW: Classification and diagnosis of myeloproliferative neoplasms: The 2008 world health organization criteria and point-of-care diagnostic algorithms. Leukemia 22: 14-22, 2008.

39. Bastos HN, Antão MR, Silva SN, Azevedo AP, Manita I, Teixeira V, Pina JE, Gil OM, Ferreira TC, Limbert E, et al: Association of polymorphisms in genes of the homologous recombination DNA repair pathway and thyroid cancer risk. Thyroid 19: 1067-1075, 2009.

40. Conde J, Silva SN, Azevedo AP, Teixeira V, Pina JE, Rueff J and Gaspar JF: Association of common variants in mismatch repair genes and breast cancer susceptibility: A multigene study. BMC Cancer 9: 344, 2009.

41. Gomes BC, Silva SN, Azevedo AP, Manita I, Gil OM, Ferreira TC, Limbert E, Rueff J and Gaspar JF: The role of common variants of non-homologous end-joining repair genes XRCC4, LIG4 and Ku80 in thyroid cancer risk. Oncol Rep 24: 1079-1085, 2010.

42. Silva SN, Azevedo AP, Teixeira V, Pina JE, Rueff J and Gaspar JF: The role of GSTA2 polymorphisms and haplotypes in breast cancer susceptibility: A case-control study in the Portuguese population. Oncol Rep 22: 593-598, 2009.
43. Sole $\mathrm{X}$, Guinó E, Valls J, Iniesta $\mathrm{R}$ and Moreno V: SNPStats: A web tool for the analysis of association studies. Bioinformatics 22: 1928-1929, 2006.

44. Geyer HL, Kosiorek H, Dueck AC, Scherber R, Slot S, Zweegman S, Te Boekhorst PA, Senyak Z, Schouten HC, Sackmann F, et al: Associations between gender, disease features and symptom burden in patients with myeloproliferative neoplasms: An analysis by the MPN QOL international working group. Haematologica 102: 85-93, 2017.

45. Figueroa JD, Malats N, Real FX, Silverman D, Kogevinas M, Chanock S, Welch R, Dosemeci M, Tardón A, Serra C, et al: Genetic variation in the base excision repair pathway and bladder cancer risk. Hum Genet 121: 233-242, 2007.

46. Wilson DM, Kim D, Berquist BR and Sigurdson AJ: Variation in base excision repair capacity. Mutat Res 711: 100-112, 2011.

47. Walter D, Lier A, Geiselhart A, Thalheimer FB, Huntscha S, Sobotta MC, Moehrle B, Brocks D, Bayindir I, Kaschutnig P, et al: Exit from dormancy provokes DNA-damage-induced attrition in haematopoietic stem cells. Nature 520: 549-552, 2015.

48. Hirotsu Y, Nakagomi H, Sakamoto I, Amemiya K, Oyama T, Mochizuki $\mathrm{H}$ and Omata M: Multigene panel analysis identified germline mutations of DNA repair genes in breast and ovarian cancer. Mol Genet Genomic Med 3: 459-466, 2015.

49. Cheadle JP and Sampson JR: MUTYH-associated polyposis-from defect in base excision repair to clinical genetic testing. DNA Repair (Amst) 6: 274-279, 2007.

50. Picelli S, Zajac P, Zhou XL, Edler D, Lenander C, Dalén J, Hjern F, Lundqvist N, Lindforss U, Påhlman L, et al: Common variants in human CRC genes as low-risk alleles. Eur J Cancer 46: 1041-1048, 2010.

51. Przybylowska K, Kabzinski J, Sygut A, Dziki L, Dziki A and Majsterek I: An association selected polymorphisms of XRCC1, OGG1 and MUTYH gene and the level of efficiency oxidative DNA damage repair with a risk of colorectal cancer. Mutat Res 745-746:6-15, 2013.

52. Tao H, Shinmura K, Suzuki M, Kono S, Mibu R, Tanaka M, Kakeji Y, Maehara Y, Okamura T, Ikejiri K, et al: Association between genetic polymorphisms of the base excision repair gene MUTYH and increased colorectal cancer risk in a Japanese population. Cancer Sci 99: 355-360, 2008

53. Qian B, Zhang H, Zhang L, Zhou X, Yu H and Chen K Association of genetic polymorphisms in DNA repair pathway genes with non-small cell lung cancer risk. Lung Cancer 73 138-146, 2011.

54. Huang M, Dinney CP, Lin X, Lin J, Grossman HB and Wu X: High-order interactions among genetic variants in DNA base excision repair pathway genes and smoking in bladder cancer susceptibility. Cancer Epidemiol Biomarkers Prev 16: 84-91, 2007.

55. Zhang Y, Newcomb PA, Egan KM, Titus-Ernstoff L, Chanock S, Welch R, Brinton LA, Lissowska J, Bardin-Mikolajczak A, Peplonska B, et al: Genetic polymorphisms in base-excision repair pathway genes and risk of breast cancer. Cancer Epidemiol Biomarkers Prev 15: 353-358, 2006.

56. Das S, Bhowmik A, Bhattacharjee A, Choudhury B, Naiding M, Laskar AK, Ghosh SK and Choudhury Y: XPD, APE1, and MUTYH polymorphisms increase head and neck cancer risk: Effect of gene-gene and gene-environment interactions. Tumour Biol 36: 7569-7579, 2015.

57. Picelli S, Lorenzo Bermejo J, Chang-Claude J, Hoffmeister M, Fernández-RozadillaC,Carracedo A,Castells A,Castellví-BelS, Memebers of EPICOLON Consortium-Gastrointestinal Oncology Group of the Spanish Gastroenterological Association and Naccarati A, et al: Meta-analysis of mismatch repair polymorphisms within the cogent consortium for colorectal cancer susceptibility. PLoS One 8: e72091, 2013.

58. Lévy N, Martz A, Bresson A, Spenlehauer C, de Murcia G and Ménissier-de Murcia J: XRCC1 is phosphorylated by DNA-dependent protein kinase in response to DNA damage. Nucleic Acids Res 34: 32-41, 2006

59. Hung RJ, Hall J, Brennan P and Boffetta P: Genetic polymorphisms in the base excision repair pathway and cancer risk: A HuGE review. Am J Epidemiol 162: 925-942, 2005.

60. Ginsberg G, Angle K, Guyton K and Sonawane B: Polymorphism in the DNA repair enzyme XRCC1: Utility of current database and implications for human health risk assessment. Mutat Res 727: 1-15, 2011

61. Jiang J, Zhang X, Yang $H$ and Wang W: Polymorphisms of DNA repair genes: ADPRT, XRCC1, and XPD and cancer risk in genetic epidemiology. Methods Mol Biol 471: 305-333, 2009. 
62. Miao X, Zhang X, Zhang L, Guo Y, Hao B, Tan W, He F and Lin D: Adenosine diphosphate ribosyl transferase and $\mathrm{X}$-ray repair cross-complementing 1 polymorphisms in gastric cardia cancer. Gastroenterology 131: 420-427, 2006.

63. Zhai X, Liu J, Hu Z, Wang S, Qing J, Wang X, Jin G, Gao J, Wang X and Shen H: Polymorphisms of ADPRT Val762Ala and XRCC1 Arg399Glu and risk of breast cancer in Chinese women: A case control analysis. Oncol Rep 15: 247-252, 2006.

64. Hu Z, Ma H, Chen F, Wei Q and Shen H: XRCC1 polymorphisms and cancer risk: A meta-analysis of 38 case-control studies. Cancer Epidemiol Biomarkers Prev 14: 1810-1818, 2005.

65. Srivastava A, Srivastava K, Pandey SN, Choudhuri G and Mittal B: Single-nucleotide polymorphisms of DNA repair genes OGG1 and XRCC1: Association with gallbladder cancer in North Indian population. Ann Surg Oncol 16: 1695-1703, 2009.

66. Chen B, Zhou Y, Yang P and Wu XT: Polymorphisms of XRCC1 and gastric cancer susceptibility: A meta-analysis. Mol Biol Rep 39: 1305-1313, 2012

67. Zou H, Li Q, Xia W, Liu Y, Wei X and Wang D: Association between the OGG1 Ser326Cys polymorphism and cancer risk: Evidence from 152 Case-Control studies. J Cancer 7 1273-1280, 2016.

68. Wei B, Zhou Y, Xu Z, Xi B, Cheng H, Ruan J, Zhu M, Hu Q, Wang Q, Wang Z, et al: The effect of hOGG1 Ser326Cys polymorphism on cancer risk: Evidence from a meta-analysis. PLoS One 6: e27545, 2011.

69. Kumar A, Pant MC, Singh HS and Khandelwal S: Role of OGG1 Ser326Cys polymorphism and 8-oxoguanine DNA damage in risk assessment of squamous cell carcinoma of head and neck in North Indian population. Mutat Res 726: 227-233, 2011

70. Wang W, Wang M, Chen Y, Zhang Z, Wang S, Xu M, Wang B, Zhao Q and Zhang Z: The hOGG1 Ser326Cys polymorphism contributes to cancer susceptibility: Evidence from 83 case-control studies. Mutagenesis 27: 329-336, 2012.

71. Canbay E, Cakmakoglu B, Zeybek U, Sozen S, Cacina C, Gulluoglu M, Balik E, Bulut T, Yamaner S and Bugra D: Association of APE1 and hOGG1 polymorphisms with colorectal cancer risk in a Turkish population. Curr Med Res Opin 27: 1295-1302, 2011.

72. Srivastava K, Srivastava A and Mittal B: Polymorphisms in ERCC2, MSH2, and OGG1 DNA repair genes and gallbladder cancer risk in a population of Northern India. Cancer 116 3160-3169, 2010

73. Gu D, Wang M, Zhang Z and Chen J: Lack of association between the hOGG1 Ser326Cys polymorphism and breast cancer risk: Evidence from 11 case-control studies. Breast Cancer Res Treat 122: 527-531, 2010.

74. Adel Fahmideh M, Schwartzbaum J, Frumento P and Feychting M: Association between DNA repair gene polymorphisms and risk of glioma: A systematic review and meta-analysis. Neuro Oncol 16: 807-814, 2014.

75. Das S, Nath S, Bhowmik A, Ghosh SK and Choudhury Y: Association between OGG1 Ser326Cys polymorphism and risk of upper aero-digestive tract and gastrointestinal cancers: A meta-analysis. Springerplus 5: 227, 2016.

76. Wenjuan C, Jianzhong L, Chong L, Yanjun G, Keqing L, Hanzhang W and Zhiping W: The hOGG1 Ser326Cys gene polymorphism and susceptibility for bladder cancer: A meta-analysis. Int Braz J Urol 42: 883-896, 2016.

77. Abbotts R and Madhusudan S: Human AP endonuclease 1 (APE1): From mechanistic insights to druggable target in cancer. Cancer Treat Rev 36: 425-435, 2010.

78. Dyrkheeva NS, Lebedeva NA and Lavrik OI: AP endonuclease 1 as a key enzyme in repair of Apurinic/Apyrimidinic sites. Biochemistry (Mosc) 81: 951-967, 2016.
79. Peng Q, Lu Y, Lao X, Chen Z, Li R, Sui J, Qin X and Li S: Association between OGG1 Ser326Cys and APEX1 Asp148Glu polymorphisms and breast cancer risk: A meta-analysis. Diagn Pathol 9: 108, 2014

80. Zhao Z, Liu C, Zeng Y, Gu L, Ying M, Wang N, Hao B, Yao H, $\mathrm{Su} \mathrm{C}$, Wang Y and Ma Y: The association between the APE1 Asp148Glu polymorphism and breast cancer susceptibility: A meta-analysis based on case-control studies. Tumour Biol 35: 4727-4734, 2014

81. Wu B, Liu HL, Zhang S, Dong XR and Wu G: Lack of an association between two BER gene polymorphisms and breast cancer risk: A meta-analysis. PLoS One 7: e50857, 2012.

82. Zhou X, Wei L, Jiao G, Gao W, Ying M, Wang N, Wang Y and Liu C: The association between the APE1 Asp148Glu polymorphism and prostate cancer susceptibility: A meta-analysis based on case-control studies. Mol Genet Genomics 290: 281-288, 2015

83. Li X, Zhang G, Huai YJ and Cao ZQ: Association between APE1 T1349G polymorphism and prostate cancer risk: Evidence from a meta-analysis. Tumour Biol 35: 10111-10119, 2014.

84. Li H, Zou J, Mi J, Wei X, Zhao D, Zhang S and Tian G: Association of APE1 Gene Asp148Glu variant with digestive cancer: A meta-analysis. Med Sci Monit 21: 2456-2466, 2015.

85. Dai ZJ, Shao YP, Kang HF, Tang W, Xu D, Zhao Y, Liu D, Wang M, Yang PT and Wang XJ: Relationship between apurinic endonuclease 1 Asp148Glu polymorphism and gastrointestinal cancer risk: An updated meta-analysis. World J Gastroenterol 21: 5081-5089, 2015.

86. Jin F, Qian C, Qing Y, Zhang Z, Wang G, Shan J, Dai N, Li Z and Wang D: Genetic polymorphism of APE1 rs1130409 can contribute to the risk of lung cancer. Tumour Biol 35: 6665-6671, 2014.

87. Hu D, Lin X, Zhang H, Zheng X and Niu W: APEX nuclease (multifunctional DNA repair enzyme) 1 gene Asp148Glu polymorphism and cancer risk: A meta-analysis involving 58 articles and 48903 participants. PLoS One 8: e83527, 2013.

88. Talhaoui I, Lebedeva NA, Zarkovic G, Saint-Pierre C, Kutuzov MM, Sukhanova MV, Matkarimov BT, Gasparutto D, Saparbaev MK, Lavrik OI and Ishchenko AA: Poly(ADP-ribose) polymerases covalently modify strand break termini in DNA fragments in vitro. Nucleic Acids Res 44: 9279-9295, 2016

89. Wei H and Yu X: Functions of PARylation in DNA damage repair pathways. Genomics Proteomics Bioinformatics 14: 131-139, 2016.

90. Qin Q, Lu J, Zhu H, Xu L, Cheng H, Zhan L, Yang X, Zhang C and Sun X: PARP-1 Val762Ala polymorphism and risk of cancer: A meta-analysis based on 39 case-control studies. PLoS One 9: e98022, 2014

91. Hua RX, Li HP, Liang YB, Zhu JH, Zhang B, Ye S, Dai QS, Xiong SQ, Gu Y and Sun XZ: Association between the PARP1 Val762Ala polymorphism and cancer risk: Evidence from 43 studies. PLoS One 9: e87057, 2014.

92. Hu Y, Zhou M, Li K, Zhang K, Kong X, Zheng Y, Li J and Liu L: Two DNA repair gene polymorphisms on the risk of gastrointestinal cancers: A meta-analysis. Tumour Biol 35: 1715-1725, 2014.

93. Lindholm Sørensen A and Hasselbalch HC: Smoking and philadelphia-negative chronic myeloproliferative neoplasms. Eur J Haematol 97: 63-69, 2016.

94. Hasselbalch HC: Smoking as a contributing factor for development of polycythemia vera and related neoplasms. Leuk Res pii: S0145-2126, 2015 